\title{
DEVELOPMENT OF RURAL GREEN TOURISM IN THE REGIONS OF UKRAINE ON THE BASIS OF EUROPEAN INTEGRATION
}

\author{
Julia Grynchuk' ${ }^{\text {, Iryna Romaniuk }}{ }^{2}$
}

\begin{abstract}
The objective of the article is to substantiate the forms, mechanisms, and directions of development of rural green tourism in the regions of Ukraine as an important means of improving the sectoral structure and territorial organization of tourism activity on the basis of the use of natural tourism resources and the employment of large numbers of unemployed rural population. Methodology. The methodological basis of the study is the dialectical method of cognition and the systematic approach to the study of phenomena and processes of the formation and development of rural green tourism in the regions of Ukraine on the basis of the use of a favourable natural potential and an excess of labour resources. Results. The article reveals the tendencies and possibilities of improving the structure and territorial organization of tourism activity on the basis of development of rural green tourism. First of all, the natural conditions and resources of the picturesque countryside, as well as the unoccupied rural population, are determined as its resources. The forms, sources, and mechanisms of the organization, proposals for granting and extending the nomenclature of services are substantiated. The prospects of using the EU experience and the advantages of European integration processes for Ukraine are revealed. Recommendations on the formation of clusters and other associations of tourist activities in the village have been developed. The field of application of results: carrying out of scientific researches in the field of development of the activity of agriculture, provision of services of rural green tourism, is one of directions of diversification and increase of incomes of rural population and improvement of its standard of living. Solving the problems of employment, organizational and economic problems related to the reproduction of labour potential in the agrarian sector and the formation of new trends in the production and marketing of agricultural products. Conclusions. The development of rural green tourism has a positive effect on solving socio-economic problems of the village, primarily in the direction of expanding the rural population's employment. Rural green tourism provides a rural population with additional income, expanding employment opportunities for rural owners, not only in the production sector but also in the service sector. With an increase in the number of vacationers, there is a need to meet their diverse needs and this, in turn, stimulates the development of services: excursions, communications, trade, life services, recreation and entertainment, and others.
\end{abstract}

Key words: tourism activity, natural and labour resources, abundance, rural green tourism, forms, mechanisms, clusters, branch structure, territorial organization, improvement.

JEL Classification: Z32, P28, J21, H62, E19

\section{Introduction}

The growing demand for various types of tourism, observed in recent years in Ukraine and in the world, leads to the conviction that tourism activity can be the basis of the use of natural and human resources for the operation of agrarian enterprises and households for a certain organizational and economic mechanism and the direction of its implementation. Traditionally, rural green tourism is grounded in this direction. The potential of development of tourist services of the mountain and seaside agrarian enterprises and agroholding of the country on the basis of the use of natural climatic and other socio-geographical conditions is not in doubt. Therefore, consideration should be given to how and to what extent rural green tourism can become a function of socio-economic activity in traditional agrarian regions, both at the level of administrative regions and at the level of administrative districts or rural areas.

Overall tourism development of any territory, the formation of tourist destinations is a complex and important environmental, social, and economic problem. Development and improvement of organizational and economic mechanism for the provision of tourism services in rural regions are feasible

\footnotetext{
Corresponding author:

${ }^{1}$ Bila Tserkva National Agrarian University, Ukraine.

E-mail: grynchuk1979@icloud.com

${ }^{2}$ Kharkiv Petro Vasylenko National Technical University of Agriculture, Ukraine.

E-mail: romaniuk.iryna@ukr.net
} 
not only because of the continuous increase in demand for tourism of various types and trends but also because of the presence of the aggregate favourable features of rural areas: dry warm climate, prevailing bright sunny day in summer, spring and autumn; proximity to water, balneological resources; unique natural, historical, architectural, cultural and artistic and other values and tourist attractions; qualified and free labour resources; tolerant and friendly people. Available and cheap quality organic food products should be added to this; therefore, interesting and cost-effective gastronomic tours may be arranged.

\section{Trends and opportunities for improving the structure and territorial organization of tourism activity on the basis of development of rural green tourism}

Rural green tourism as an important direction of tourism activity is based on the use of traditional natural resource potential and rural lifestyles. However, for city dwellers, tourists from other countries, it as well as natural attractions can be perceived as unique or exotic. In any case, vacationers are attracted by nature, the ability to communicate with animals, participation in agriculture, etc. (Vrakhovych, Franchuk, 2013). Taking into account the fact that objects that are often attractive to tourists are far beyond the boundaries of large cities, the efficient way in the organizational and economic mechanism of providing rural green tourism services to agrarian enterprises may be the creation of a network of clusters as systems and links of tourist facilities with small towns.

They are economically feasible and beneficial for the short-term provision of services to small groups of vacationers (as a rule, family holidays on weekends and holidays). Creation of a special service centre in such conditions is not feasible because its functions can be performed by a set of enterprises and organizations of a small town. Placing small tourist objects of agroindustries in the vicinity of a small town allows them to connect to town infrastructure, use technical and utility facilities, and provide the necessary personnel. A small town can become the centre for rural green tourism and service tourism activities in general for the entire administrative district.

In rural areas that do not have the conditions for the organization of special tourist facilities, tourist services can be provided in existing rural settlements. We are talking about agrarian tourism, which is understood as a recreational type of tourism, which involves staying of tourists in agrarian enterprises and rural households (Ihnatenko, 2010). It involves the development of tourist routes and directions, places for recreation, agricultural and folk museums of local lore, as well as tourist centres with guides and tourists, etc. It should be noted that even at the launch stage, rural green tourism requires relatively small investments and is a sector where the creation of new jobs does not require special or additional professional knowledge and skills. The services of rural green tourism by agrarian enterprises can become a solution to problems for those representatives of the rural population who have lost their jobs or were forced to leave their work in agricultural production through its digitization and corporatization.

In the long term, the organizational and economic provision of tourism development, the improvement of its structure and territorial organization on the basis of providing tourist services in the countryside, the following decisive feature of rural green tourism should be taken into account: it cannot be represented by a clearly defined standardized set of services and attractions (accommodation, food, excursions, hunting, participation in local ceremonies, acquaintance with crafts, etc.). The variety of their recruitment depends on the host party (owners of dwellings, farms, other agrarian or agro-industrial enterprises). However, it can be argued that the main product of rural green tourism is the hospitality service, i.e. the ability to organize tourists holiday in such a way that they would like to return to the owners more than once (Marmul, Pinchuk, 2009).

In the employment system, rural green tourism occupies an intermediate position between the services of accommodation (mini-hotels in Poland) and the use of their own homes for personal (family) needs only (in Ukraine). Given that the unemployment rate in the countryside is much higher than in urban areas, rural green tourism provides an opportunity for additional earnings, using the "abundance" of residential premises and other facilities adapted for the reception of tourists. However, in Ukraine, the certification of housing on the level of comfort and other standards, although, has the proper theoretical and methodological justification, in practice, requires comprehensive implementation and confirmation.

Also, the development of rural green tourism services by agrarian enterprises in the country is mainly nonsystemic. By satisfying the growing demand for rest, hundreds of owners of farmhouses and farms try to develop this kind of business on their own, accompanied by a number of problems: lack of experience in organizing their own business; limited access to information (how to start a tourism activity, and on further advertising, customer search, etc.); limited material resources for creating or improving the conditions for servicing tourists, etc. (Romaniuk, 2017).

\section{Prospects for using the EU experience and the advantages of European integration processes for Ukraine}

The association of individual representatives of rural green tourism into unions, organizations of various levels allows coordinating the activities of participants 
in a certain direction, providing methodological, informational, and advisory assistance, promoting targeted funding in accordance with development programs, protecting interests in state and local government bodies. The research showed that the industry is paying much attention to the development of cooperation with the European Union (EU) in view of the possibility of promoting a national tourism product in the European market, involvement in the information space, best practices in organizing tourism activities, and strengthening European integration processes in our country. In terms of its tourist potential, Ukraine is best placed to become one of the leading European tourist countries.

EU membership opens new perspectives for using the organizational and financial mechanisms of this body to increase the economic efficiency of the national tourism industry. Taking into account this, through the Special Representation of Ukraine to the EU, the tourist office of Ukraine has applied for inclusion of the country in perspective programs of cooperation in the field of tourism, in particular, financial and technical assistance, as well as investment projects of the EU. This would have a qualitative effect on the development of the sectoral tourism activity of the country, would contribute to the socio-economic and cultural development of our country and regions (Yermakov, 2008).

It should be noted that the tourism sector of the national economy in terms of shifts in the organizational and economic mechanism of management was characterized by active privatization processes in the 1990s - early 2000s. During the last period, almost all state enterprises were privatized by corporatization and creation of joint-stock companies as a hotel and restaurant business, and in the resort and recreation sphere. There is a tendency to achieve $100.0 \%$ of the level of privatization. This, in turn, has created certain, for example, prerequisites for the development of small and medium-sized enterprises in the field of rural green tourism, taking into account the growth of the number of mini-hotels, mini-farms, and other organizational formations in the village that provide the relevant services, etc.

The authorities are also interested in participating in the TACIS National Program for Ukraine, which was set up to support small and medium-sized enterprises in order to ensure the effective functioning of the tourism infrastructure in the directions of international transport corridors. The country adopted the Program for the development of tourism infrastructure in the directions of the national network of international transport corridors and main transport highways in 2004-2010. It was approved by the Resolution of the Cabinet of Ministers of Ukraine No. 612 as of May 12, 2004. The primary measures for the construction of transport corridors are the construction, reconstruction of roads, and the arrangement of the tourist infrastructure and other objects of service. The general objective of the program was to equip the national network of international transport corridors with modern tourist infrastructure, to promote the creation of a competitive national tourism product, and to ensure the sustainable development of the national network of international transport corridors (Dvornyk, 2014). Activation of privatization processes and an increase of citizens' incomes have led to an increase in the amount of money spent on recreation, and as a consequence - an increase in the number of trips and improvement of travel and hotel infrastructure. It was also strongly encouraged by the European Football Championship Euro-2012 and other European-level cultural, artistic, and sporting events.

In our opinion, the basic principle of development of tourist activity in the village is the improvement of the existing organizational and economic model of its implementation. It is necessary to create such an organizational-management structure or network that would provide comprehensive not only productive and economic or resource support but also advisory and methodological assistance in the organization of rural green tourism. It should also distribute advertising and information on tourism opportunities in rural areas, assist in finding sources of financing and investing tourism objects, etc.

When introducing a new model of rural green tourism, it is necessary to reconcile legal, organizational, and economic measures to achieve the main goal - effective socio-economic development of agrarian enterprises on the basis of diversification of their activities by providing tourist services. It should be borne in mind that the regulation of rural green tourism services is based on the current legal framework of the country: the Constitution of Ukraine, the Civil Code, the Housing Code, (Laws of Ukraine "On Tourism”, 1995, "On Private Peasant Economy", 2003) and other. At the regional level, regulation is carried out on the basis of regulatory and program documents of local authorities and self-government, including tourism development programs, strategies of economic and social development of administrative regions for the period up to 2020 .

According to the draft (Law of Ukraine "On Rural Green Tourism”, 2007), tour operators, travel agents, individuals who are not entrepreneurs and business entities providing temporary accommodation services (accommodation), catering, sightseeing, entertainment and other tourist services (including tourist support) act as the subjects in the field of its implementation. However, in our opinion, state and regional authorities, public organizations involved in regulation and popularization of tourism activity on the basis of agrarian enterprises, farms and agro- homes should be included in the organizational block.

In the administrative areas of the country, the organizational and economic mechanism for the 
development of rural green tourism services in agrarian enterprises and agro-homes, in addition to these areas of improvement, requires appropriate measures at the level of local authorities in terms of using regulatory and support instruments. In modern conditions, the main functions, related to the regulation and development of this type of activity, are assigned to regional departments of physical culture, sports, and tourism. However, they are reduced, mainly, to the collection and recording of statistical information on tourism, including rural green (Ivanova, 2014). In districts and cities, even in the centres of the overwhelming majority of administrative areas, profile state bodies function formally as passive observers. This does not correspond to the Resolution of the Cabinet of Ministers of Ukraine "On Approval of Model Provisions on Region, District Departments (Branches) on Tourism and Resorts..." Among the public organizations involved in the development of mainly sports tourism are urban tourism and sports clubs, regional representative offices of the Sports Tourism Federation, etc.

Based on the identified problems of tourism development in the rural areas, we have substantiated the model of its organization and management (Figure 1). It is based on the creation of voluntary territorialsectoral integration of enterprises that work closely with scientific institutions and authorities to improve the competitiveness of services and economic growth. Such an association is created and operates in the form of a public non-profit organization or cluster in accordance with the Law of Ukraine "On Citizens' Associations" and the current legislative and regulatory framework. Its purpose is to protect legal rights and interests, to coordinate the participation and cooperation of the participants of the association aimed at developing tourism activities in the region (Illiashenko, Iliashenko, Shcherbachenko, 2013).
The economic block of its organizational and economic mechanism should include: 1) the mechanism of pricing, taxation, marketing, standardization, etc. These issues are not yet regulated at the state level and are solved by the participants of rural green tourism; 2) the mechanism of functioning of the tourist's integral structure itself.

\section{Recommendations for the creation of clusters and other associations of tourist activities in the rural areas}

Starting financial and economic conditions of an association or cluster will be the following: a) expenses for creation and registration of the association; b) organizational and administrative expenses; c) cost of information provision for all interested parties; d) expenses for the creation (improvement) of conditions of reception of tourists (concerning place of living, various kinds of attractions). Given that such an association is a public organization, sources of funding for these costs are: membership fees, sponsorship (charity) assistance, funds from grants and projects, funds for the implementation of relevant state and regional tourism development programs, poverty reduction in rural areas, housing construction, etc.

At the initial stage of functioning of such integrated groups or clusters, it is expedient to establish cooperation with regional and district employment centres and the Fund of Compulsory State Social Insurance of Ukraine in case of unemployment through: 1) conducting seminars for informing the population of regions about the essence of rural green tourism and opportunities and resources for participation in it; 2) provision of onetime assistance for the opening of their own business (for example, for the arrangement of comfortable conditions for the reception of tourists, their transfer, excursions or the creation of tourist agro-villages).

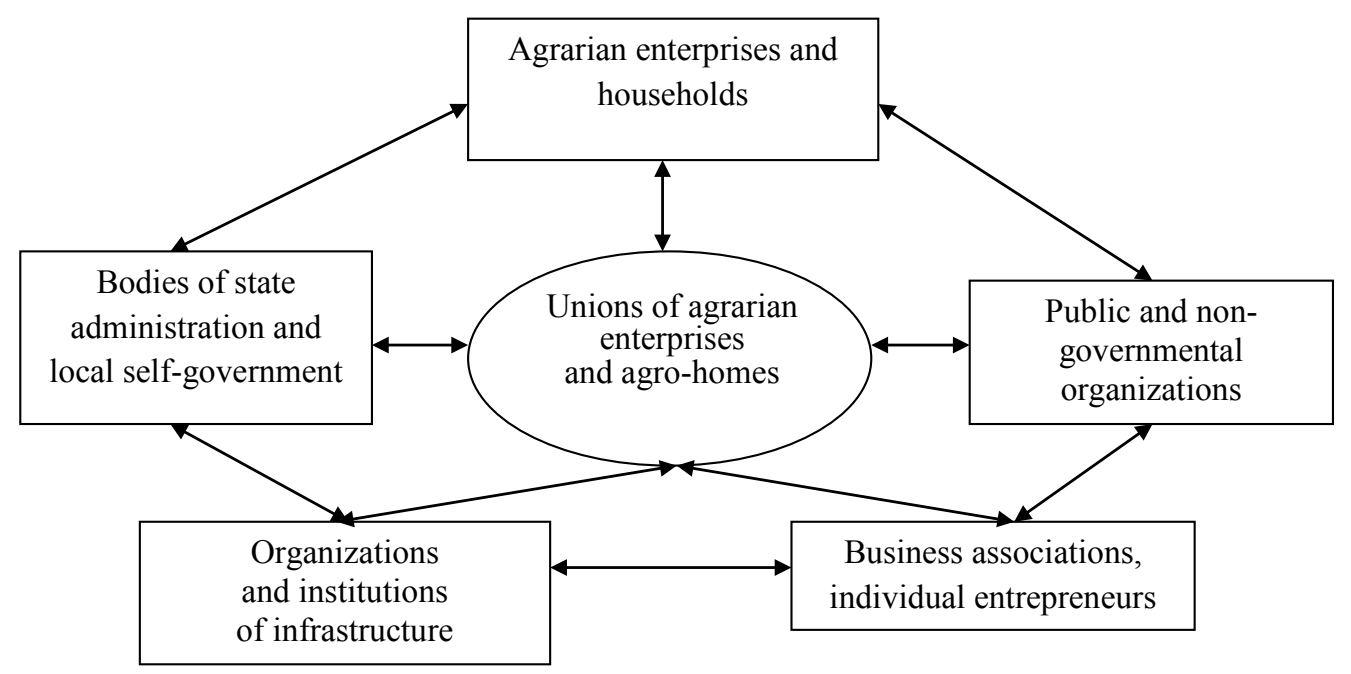

Figure 1. Model of organization and management of integral formation (cluster) of agrarian and other enterprises, institutions, and organizations providing tourist services in rural areas 
The services of rural green tourism create jobs and bring certain incomes to rural people who find it difficult to make money in another way. The development of this type of tourism activity prompts improvement of the upgrading of rural and farm enterprises, agro-villages, streets, and villages in general; stimulates the placement of social infrastructure institutions. Of course, the first time reception and service of vacationers are based on existing housing stock with the use of local tourist and infrastructural resources. But with gradual revenues and an increase in the cost of tourism, those who are engaged in it are beginning to make investments in improving the communal housing, street and service sectors. And this, at the same time, is a significant contribution to the development of rural areas. An example can be the creation of local branches of the Union for the Promotion of Rural Green Tourism, district associations of citizens and/or institutions interested in infrastructure development for it.

In our opinion, the main features of the implementation of rural green tourism services in agrarian formations, which must be taken into account as possible risks and which influence its development in the future, are as follows: regulatory and legislative acts and conditions for the development of rural green tourism services in agrarian enterprises and agro-villages are still not specified finally; most providers of such services work "in the shadow", despite the favourable tax environment; full activity statistics are practically not required and not conducted, which complicates the monitoring of relevant markets, trends and forecasts; rural green tourism services are concentrated and implemented unevenly in spatial terms.

As noted, the development of rural green tourism, in general, is now stimulated by state authorities, local authorities, rural communities, but not too systematically (Kudinova, 2008). The agro-homes, which take tourists, are different - from the simplest, with minimal comfort and moderate prices to very expensive with a full set of services. This holds back the demand for their services because vacationers cannot always imagine them. The question is whether rural dwellings can be defined as agro-homes since these buildings do not quite match the criteria of classical agro-villages, which actively offer rural green tourism. It has up to five rooms; the owners are engaged in agricultural activities or work in the social sphere of the village.

Most of the abovementioned problems of rural green tourism services of agrarian enterprises of the country are characteristic for all regions. However, some regions have specific problems. Among them the most significant are: insufficient number of enterprises of logistics, advertising, service and information infrastructure; limited availability of investment support for tourism activities in agrarian enterprises and agro-villages; lack of general plans for the development of tourist destinations; lack of funding support for the promotion of a regional rural tourism product in the domestic and international tourist services market; slow introduction of innovations in order to develop them.

\section{Conclusions}

The identification of problems and trends in tourism development in the rural areas allowed developing proposals for its improvement. Important ways of developing rural green tourism for agrarian enterprises and households are improving the quality and competitiveness of tourist services; development of local standards for the assessment of places of recreation; certification of places of accommodation of tourists; conducting annual competitions for the title of "the best rural tourism enterprises and agro-homes".

It is also the detailing, growth, and disclosure of meaningful information on tourism potential; creation of music videos, popular science films about the most interesting regional attractions, access to them on the Internet, on television channels of the states where potential tourists live; publication of literature of local lore, adapted to different categories of tourists; the introduction of tourist-linguistic disciplines in accordance with their placement: "Ukrainian Black Sea Region”, “Tourist Bukovyna”, "Picturesque Polissia”, "Transcarpathia Invites", etc. It is advisable to issue booklets, newspapers, magazines on tourist topics for the distribution in transport, in service facilities, tourism. It is necessary to hold scientific conferences, workshops, tourist forums, fairs, roundtables, etc. In general, the development of rural green tourism will contribute to the rational use of natural potential and labour released from agricultural production in the rural regions of Ukraine.

\section{References:}

Vrachovich, I. M., Franchuk, Yu. O. (2013). Mekhanizmy stymulyuvannya «zelenoho» investuvannya rehionalnoyi ekonomiky [Mechanisms for stimulating the «green» investment of a regional economy]. Economic forum, vol. 3, pp. 54-59.

Ihnatenko, M. M. (2010). Sotsialno-ekonomichni aspekty aktyvizatsiyi ahroturystychnoyi diyalnosti [Socioeconomic aspects of activization of agro-tourism activity]. Proceedings of the Participation of youth in the development of economy and society of Ukraine (Ukraine, Kyiv, March 10, 2010), Kyiv: NAKKKIM, pp. 243-246.

Marmul, L. O., Pinchuk, T. A. (2009). Orhanizatsiya ta rozvytok ahrarnoho turyzmu v rehioni [Organization and development of agrarian tourism in the region]. Kherson: Aylant (in Ukrainian).

Romaniuk, I. A. (2017). Rozvytok silskoho zelenoho turyzmu v umovakh neobkhidnosti dyversyfikatsiyi silskoyi ekonomiky [Development of rural green tourism in the conditions of necessity of diversification of rural economy]. 
Stratehichni napryamy sotsialno-ekonomichnoho rozvytku ahrarnoho sektoru ekonomiky Ukrayiny [Strategic directions of socio-economic development of agrarian sector of economy of Ukraine]. Kherson: LLC "VKF" STAR "LTD, pp. 299-307.

Ermakov, O. Yu. (2008). Rozvytok silskoho turyzmu yak vazhlyvyy napryam dyversyfikatsiyi ahrarnoyi ekonomiky [Development of rural tourism as an important direction in the diversification of agrarian economics]. Tavriysky Scientific Bulletin, vol. 58, pp. 153-156.

Dvornik, I. V. (2014). Dyferentsiatsiya dokhodiv silskoho naselennya Ukrayiny [Differentiation of income of the rural population of Ukraine]. Economy of AIC, vol. 11, pp. 101-106.

The Verkhovna Rada of Ukraine (1995). Pro turyzm: Zakon Ukrayiny vid 15 veresnya 1995 roku № 324/95-VR [On Tourism: Law of Ukraine dated September 15, 1995 no. 324/95-VR]. Bulletin of the Verkhovna Rada of Ukraine, vol. 31, Art. 241.

The Verkhovna Rada of Ukraine (2003). Pro osobyste selyanske hospodarstvo: Zakon Ukrayiny vid 15 travnya 2003 roku № 742-IV [About personal peasant economy: Law of Ukraine dated May 15, 2003 no. 742 -IV]. Bulletin of the Verkhovna Rada of Ukraine, vol. 29. Art. 232.

Pro silskyy zelenyy turyzm: proekt Zakonu Ukrayiny vid 12.04.2007 r. №346 [About rural green tourism: the draft Law of Ukraine dated April 12,2007. no. 3467]. Retrieved from: http://tourlib.net/zakon/pro_siltur.htm (accessed 23 June 2018)

Ivanova, V. V. (2014). Lyudskyy kapital yak chynnyk zabezpechennya konkurentospromozhnosti pidpryyemstv turystychnoho biznesu [Human capital as a factor for providing competitiveness of tourist business enterprises]. Current problems of the economy, vol. 5, pp. 321-327.

Ilyashenko, S. M., Ilyashenko, N. S., Shcherbachenko, V. O. (2013). Zelenyy turyzm yak odyn z napryamiv staloho rozvytku rehionu [Green tourism as one of the directions of sustainable development of the region]. Economy of Ukraine, vol. 8, pp. 33-39.

Kudinova, I. P. (2008). Zelenyy turyzm yak odyn iz napryamiv rozvytku pidpryyemnytstva v silskiy mistsevosti [Green tourism as one of the areas of entrepreneurship development in rural areas]. Scientific Bulletin of the National Agrarian University, vol. 124, pp. 91-96. 